\title{
Does Privatization of a Postal Savings Bank in Japan Have Economic Value?*
}

\author{
Ken-Ichiro Oohama ${ }^{1}$, Yoshihiro Asai ${ }^{2}$ \\ ${ }^{1}$ Asahi University, Gifu, Japan; ${ }^{2}$ Josai University, Sakado, Japan. \\ Email: oohama@alice.asahi-u.ac.jp,yasai@josai.ac.jp \\ Received June $17^{\text {th }}, 2011$; revised July 22 $2^{\text {nd }}, 2011$; accepted August $10^{\text {th }}, 2011$.
}

\begin{abstract}
Economic theory traditionally supports the viewpoint that government ownership is inefficient and that privatization invariably leads to efficiency improvements. However, there is often frequent opposition to privatization activity because it is difficult to examine and empirically validate the effects of privatization. This is the first study to examine the impact of the privatization of postal saving banks. In this paper, we use event study and find that impacts of the privatization of a postal savings bank in Japan are evaluated as positive. We also find that the privatization of the postal savings bank threatened other banks in rural areas that had hitherto enjoyed a regional monopoly.
\end{abstract}

Keywords: Privatization, Postal Savings Banks, Event Study

\section{Introduction}

Economic theory traditionally supports the viewpoint that government ownership is inefficient and that privatization invariably leads to efficiency improvements. On this basis, the privatization or reform of postal savings banks has accelerated around the world and [1] introduce several international cases. However, it is only relatively recently that there has been full consideration of privatization outcomes, mainly because it is difficult to identify their impact. There is often opposition and criticism of privatization because of the failure to identify its positive impacts.

However, recent developments in the study of privatization have enabled researchers to better test the impacts of privatization. Work by [2] is an example of some of the pioneering research in this field. [2] argue that we can infer investors' expectations of the efficiency improvement associated with privatization from changes in the stock prices of rival firms following the privatization announcement (see Figure 1).

Using this approach, [3] investigate the impact of bank privatization and conclude that the privatization of stateowned banks has led to positive efficiency improvements. However, the number of studies investigating the impact of privatization remains limited and there has been no

\footnotetext{
*The authors gratefully acknowledge the financial support of a Grantin-Aid for Scientific Research (KAKENHI). All remaining errors are our responsibility.
}

particular consideration of the effects of the privatization of postal savings banks. Therefore, this is the first study to examine the impact of the privatization of postal saving banks.

We undertake this analysis in the Japanese context because the Japan Post Bank (a privatized postal savings bank) is the eighth largest deposit-taking financial institution in the world in terms of the volume of deposits, according to both Data Stream and the Japan Post Bank's own disclosures (see Table 1). That is, the Japan Post Bank is not only the world's largest postal savings sys-

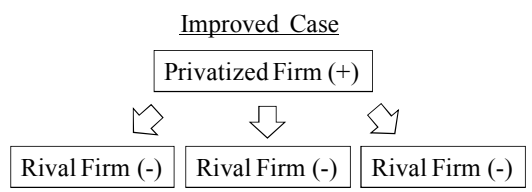

If a privatized firm becomes more efficient, then it gives negative impacts (-) for rival firms.

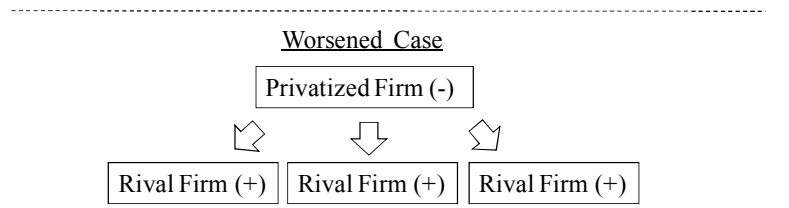

If a privatized firm becomes less efficient, then it gives positive impacts $(+)$ for rival firms.

Figure 1. The privatization effects inferred from rival firms' reaction. 
Table 1. World's twenty largest banks.

\begin{tabular}{|c|c|c|}
\hline \multicolumn{3}{|c|}{ Assets (\$US Millions) } \\
\hline 1 & The Royal Bank of Scotland & $3,777,312$ \\
\hline 2 & Deutsche Bank & $2,946,766$ \\
\hline 3 & BNP Paribas & $2,474,846$ \\
\hline 4 & Barclays & $2,440,272$ \\
\hline 5 & HSBC Holdings & $2,356,645$ \\
\hline 6 & Citigroup & $2,187,631$ \\
\hline \multirow[t]{2}{*}{7} & Crédit Agricole & $2,064,099$ \\
\hline & Yucho Bank & $2,025,575$ \\
\hline 8 & Union Bank of Switzerland & $2,004,687$ \\
\hline 9 & Bank of America & $1,715,746$ \\
\hline 10 & Mitsubishi UFJ Financial Group & $1,583,924$ \\
\hline 11 & Société Générale & $1,562,332$ \\
\hline 12 & JP Morgan Chase & $1,562,147$ \\
\hline 13 & Unicredito Italiano & $1,482,930$ \\
\hline 14 & HBOS & $1,327,624$ \\
\hline 15 & Banco Santander Central Hispano & $1,318,812$ \\
\hline 16 & Fortis Uhren & $1,270,005$ \\
\hline 17 & Mizuho Financial Group & $1,266,068$ \\
\hline 18 & Credit Suisse & $1,196,759$ \\
\hline 19 & Industrial and Commercial Bank of China & $1,188,082$ \\
\hline 20 & Zhongguo Jianshe Yinhang & 903,347 \\
\hline
\end{tabular}

Note: (Source: Data Stream and Yucho Bank disclosures, as at March 2008).

tem, but also one of the world's largest financial institutions. Therefore, it is appropriate for us to examine the Japanese case to understand better the effects of bank privatization.

\section{The Japanese Financial System and the Postal Savings Bank}

In 1871, the national government in Japan established a modern postal service, with postal savings services commencing in 1875. Accordingly, the Japanese government has provided postal services and savings for more than 130 years. However, despite the ongoing contribution of the government-owned postal savings bank to raising funds for the government to construct social infrastructure, in 2001 it was privatized. See [4] for details. The most important consideration associated with privatization is whether the postal savings bank could operate more efficiently with the change in ownership.
That is, the focus of the economics literature has been whether privatization leads to an improvement in enterprise efficiency, as considered in [2] and [3].

As shown in Table 1, the Japanese postal savings bank was not only quite a large financial institution, but also enjoyed a number of privileges and immunities, including the remission of property tax. For this reason, rival private banks have argued for the privatization of the postal savings bank for some time because it left the private banks at a competitive disadvantage. With the abolishment of these privileges and immunities after privatization, there was also allowance for the postal savings bank to enter new business lines (e.g. the sale of mutual funds) and this meant that it became a potentially larger threat to rival private banks. In other words, while privatization could make the postal savings bank stronger and more efficient given its access to new business opportunities, privatization could also make it weaker and less efficient because of the loss of the privileges and immunities it enjoyed previously. In the latter situation, the privatization of the bank would represent a valuable opportunity for rival private banks (see Figure 2). Therefore, an empirical study is the best approach for investigating the impact of privatization.

\section{Data and Methodology}

Usually, a national election raises several important issues. However, the main issue arising in Japan's 44th lower house general election in September 2005 concerned the postal savings bank after the upper house voted down the necessary postal privatization bills in August 2005. With this in mind, the then prime minister, Junichiro Koizumi, dissolved the lower house and called an election to ask the Japanese people whether the postal

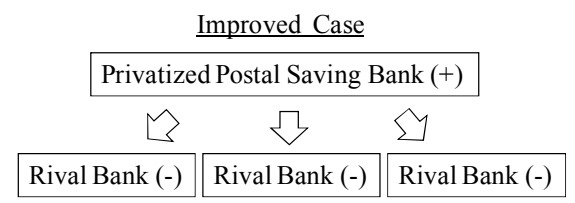

If a privatized postal saving bank becomes more efficient, then it gives negative impacts (-) for rival bank.

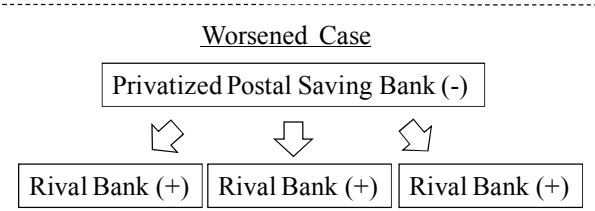

If a privatized postal saving bank becomes less efficient, then it gives positive impacts $(+)$ for rival bank.

Figure 2. The privatization effects inferred from rival banks' reaction. 
savings banks should be privatized. Koizumi's Liberal Democratic Party won in a landslide, gaining additional seats, following which the program of postal privatization accelerated.

However, the day before the election, the media reported that the election result was difficult to predict. That is, the stock market did not have enough information to anticipate the election result. Therefore, it is appropriate to identify the day after the election as the event day. Following [5], who analyzed the impact of bank failure on client firms using Japanese data, we employ a standard event study methodology. For any security $i$, the market model is:

$$
R_{i t}=\alpha_{i}+\beta_{i} R_{m t}+\varepsilon_{i t}
$$

where $R_{i t}$ and $R_{m t}$ are period $t$ returns on security $i$ and the market portfolio, respectively, and $\varepsilon_{i t}$ is the zero-mean disturbance term. $\beta_{i}$ represents the market beta and $\alpha_{i}$ represents intercept. We use the Tokyo Stock Exchange Price Index (TOPIX) to calculate the market portfolio returns. The estimation period is 230 trading days, beginning 240 days before the initial public announcement of the event.

\section{Empirical Results}

Table 2 presents the cumulative abnormal returns (CAR). As shown, the impact of bank privatization on shareholder value in rival private banks is statistically significantly negative at the $1 \%$ level for the full sample on the event day ( $t$-value $=-2.5550)$. As in [2] and [3], we interpret this result as suggesting that the privatization of the postal savings bank in Japan would lead to efficiency improvements. In other words, the privatization of the postal savings bank resolved the inefficiency arising from government ownership and thus privatization leads to an efficiency improvement.

Table 2. Counterparts' reaction to privatization announcements.

\begin{tabular}{ccc}
\hline & \multicolumn{2}{c}{ All banks $(N=75)$} \\
\cline { 2 - 3 } & CAR & $t$-value \\
\hline CAR $(-5,5)$ & 0.0174 & 1.0568 \\
CAR $(-4,4)$ & 0.0123 & 0.9109 \\
CAR $(-3,3)$ & 0.0003 & 0.0270 \\
CAR $(-2,2)$ & -0.0011 & -0.1445 \\
CAR $(-1,1)$ & -0.0031 & -0.6876 \\
CAR $(0,0)^{*}$ & -0.0038 & $-2.5550^{* *}$ \\
\hline $\begin{array}{l}\text { Note: }{ }^{* *}{ }^{*} \text { and }{ }^{* * *} \text { indicate significance at the } 10 \%, 5 \% \text { and } 1 \% \text { levels, re- } \\
\text { spectively. }\end{array}$ &
\end{tabular}

We next divide the sample into urban banks not located in very large cities (such as ordinance-designated cities) and banks located in rural areas (see Figure 3). Table 3 indicates that the impact of bank privatization on the shareholder value of rival private banks was significantly negative for banks in rural areas on the event day. However, there is no significant positive or negative effect on banks in urban areas.

In other words, the results suggest that the privatization of the postal savings bank would not only entail an efficiency improvement but also that it would discipline banks in regional areas that have hitherto enjoyed a regional monopoly by enhancing consumer choice thorough increased competition. That is, the privatization of the postal savings bank represented a competitive threat to banks located in rural areas.

\section{Conclusions}

In this paper, we investigated the effects of the privatiza-

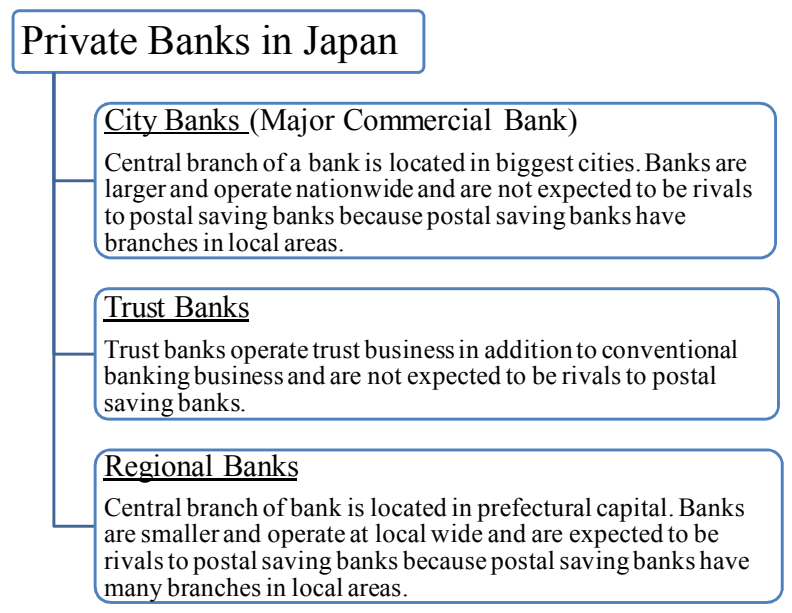

Figure 3. The banking system in Japan.

Table 3. Counterparts' reaction to privatization announcements (urban versus rural).

\begin{tabular}{lcccc}
\hline & \multicolumn{2}{c}{ Urban areas $(N=20)$} & \multicolumn{2}{c}{ Rural areas $(N=48)$} \\
\cline { 2 - 5 } & CAR & $t$-value & CAR & $t$-value \\
\hline CAR $(-5,5)$ & 0.0430 & 1.2212 & 0.0055 & 0.2790 \\
CAR $(-4,4)$ & 0.0364 & 1.2631 & 0.0021 & 0.1307 \\
CAR $(-3,3)$ & 0.0164 & 0.7317 & -0.0079 & -0.6323 \\
CAR $(-2,2)$ & 0.0062 & 0.3854 & -0.0028 & -0.3104 \\
CAR $(-1,1)$ & -0.0026 & -0.2724 & -0.0046 & -0.8457 \\
CAR $(0,0)$ & -0.0028 & -0.8761 & -0.0042 & $-2.3328^{* *}$ \\
\hline $\begin{array}{l}\text { Note: }{ }^{*}{ }^{* *} \text { and }{ }^{* * *} \text { indicate significance at the } \\
\text { spectively. }\end{array}$ & \multicolumn{4}{c}{. }
\end{tabular}


tion of the Japanese postal savings bank following the method in [2]. Using a standard event study methodology, we performed traditional $t$-tests. Consistent with [3] finding that the privatization effect of state-owned banks was positive, our analysis suggests that the privatization of the postal savings bank would lead to an improvement in efficiency thorough increased competition with private banks.

We also find that the negative impacts of postal savings bank privatization are significantly larger for regional banks and banks in rural areas. In other words, privatization will work as a threat to banks in regional areas that once enjoyed a regional monopoly and consumers in rural areas will begin enjoying a variety of financial products in both private banks and the privatized postal savings bank because of increased competition. This result suggests that privatization will potentially contribute to enhancing consumer choice in rural areas of Japan.

Our results contribute to the lines of work examining the impact of privatization, including [2] and [3]. The results of this study also have policy implications that the trend in privatization policy of state-owned enterprises and postal savings banks is desirable and worthy of further promotion.

A final comment relates to future research in this area. Certainly, while Japan is the best situation to analyze the impact of postal savings bank privatization, the sample size in our analysis is necessarily limited. Thus, other studies are called for on the impact of postal savings bank privatization to better judge any privatization effects in this particular context and enable the development of a more general conclusion.

\section{REFERENCES}

[1] M. A. Crew, P. R. Kleindorfer and J. I. Campbell Jr., "Handbook of Worldwide Postal Reform," Edward Elgar, Cheltenham, 2009.

[2] C. Eckel, D. Eckel and V. Singal, "Privatization and Efficiency: Industry Effects of the Sale of British Airways," Journal of Financial Economics, Vol. 43, No. 2, 1997, pp. 275-298. doi:10.1016/S0304-405X(96)00893-8

[3] I. Otchere, "Competitive and Value Effects of Bank Privatization in Developed Countries," Journal of Banking and Finance, Vol. 33, No. 2, 2009, pp. 2373-2385. doi:10.1016/i.jbankfin.2009.06.014

[4] Y. Kaneko and M. Metoki, "Postal Savings for National Development-The Experience of Japan and Future Perspective in a Globalized World," Public Organization Review, Vol. 8, No. 3, 2008, pp. 233-252. doi:10.1007/s11115-008-0052-9

[5] N. Yamori and A. Murakami "Does Bank Relationship Have an Economic Value? The Effect of Main Bank Failure on Client Firms," Economics Letters, Vol. 65, No. 1, 1999, pp. 115-120. doi:10.1016/S0165-1765(99)00133-0 